\title{
A Study of Multistage/Multifunction Column for Fine Coal Cleaning CRADA PC93-005, Final Report
}

\author{
Ralph Lai \\ Shiao-Hung Chiang \\ Daxin $\mathrm{He}$ \\ Yuru Feng
}

September 4, 1998

U.S. Department of Energy

Federal Energy Technology Center

P.O. Box 10940

626 Cochrans Mill Road

Pittsburgh, PA 15236-0940

and

University of Pittsburgh

Office of Research

350 Thackeray Hall

Pittsburgh, PA 


\section{Disclaimer}

This report was prepared as an account of work sponsored by an agency of the United States Government. Neither the United States Government nor any agency thereof, nor any of their employees, makes any warranty, express or implied, or assumes any legal liability or responsibility for the accuracy, completeness, or usefulness of any information, apparatus, product, or process disclosed, or represents that its use would not infringe privately owned rights. Reference herein to any specific commercial product, process, or service by trade name, trademark, manufacturer, or otherwise does not necessarily constitute or imply its endorsement, recommendation, or favoring by the United States Government or any agency thereof. The views and opinions of authors expressed herein do not necessarily state or reflect those of the United States Government or any agency thereof. 


\section{DISCLAIMER}

Portions of this document may be illegible in electronic image products. Images are produced from the best available original document. 


\author{
REPORT ON \\ FETC-DOE/UNIVERSITY OF PITTSBURGH CRADA \\ Agreement No. PC-93-005 \\ September 4, 1998
}

PROJECT TITLE:

PROJECT DIRECTORS:

RESEARCH ASSOCIATES: Daxin He, Yuru Feng

PARTICIPATING STUDENTS: Greg Diffendal, S. A. Guelcher, Xuqing Gu, Kim Jenkins

\section{A STUDY OF MULTISTAGE/MULTIFUNCTION COLUMN FOR FINE COAL CLEANING}

\author{
Ralph Lai and Shiao-Hung Chiang
}

PERIOD OF PERFORMANCE: August 1993 to August 1998

OBJECTIVES: The overall objective of the this research project is to explore the potential applicability of a multistage column for fine coal cleaning and other applications in fluid/particle separation. The research work identifies the design parameters and their effects on the performance of the separation device. The results of this study provide an engineering data basis for further development of this technology in coal cleaning and in general areas of fluid and particle separations.

HIGHLIGHT ACCOMPLISHMENTS: Improving the recovery of clean coal without sacrificing product quality is an important goal for coal cleaning processes. The technical challenge lies in the development of efficient devices that would improve the recovery of clean coal without impairing the product coal quality. The multistage flotation column equipped with draft-tube contactors proposed for this research study is aimed at meeting this challenge. The major accomplishments of this research project are summarized below:

- Experimental work was conducted to study the effects of hydrodynamic behavior in the agitated column on the coal cleaning performance. Extensive column flotation experiments were carried out in both a multistage column and a conventional column at various operating conditions.

- Comparing to the conventional column, the multistage column has been shown to be capable of achieving much higher heating value recovery (HVR $>95 \%$ ) without losing the quality of clean coal product (pyritic sulfur removal $>75 \%$ ). Optimal cleaning performance occurred under operating conditions at low superficial gas velocity $(0.6-1 \mathrm{~cm} / \mathrm{s})$, medium high agitation speed (1200-1500 RPM) and an appropriate amount of frother dosage $(\mathrm{MIBC}=20 \mathrm{ppm})$.

- A non-agitated, high aspect ratio multistage column was constructed to explore extending the application of this novel column to more general fluid/particle separation areas, including $\mathrm{oil} /$ water separations and metal oxide removal from wastewater. The results showed great 
potential of this column in oily wastewater treatments and in removing metal oxides from waste stream discharged from nuclear power plants.

- A semi-empirical model has been successfully developed to simulate the multistage column cleaning process. The model provides necessary information for the scale-up of the multistage column.

- The result of an economic analysis showed that the overall processing cost of the multistage column is lower than the comparable operation of conventional flotation devices.

\section{PUBLICATIONS AND PRESENTATIONS}

1. F. Ding, and S. H. Chiang, "Removal of Oil from Oily Waste Water Using Multi-stage Loop Flotation Column," 7 , 149-150, Fluid/Particle Separation Journal.

2. X. Gu, S. A. Guelcher, D.X. He, and S. H. Chiang, "The Use of a Multi-stage Flotation Column for Solid-Solid Separation," presented at 1996 AFS Annual Technical Conference, Valley Forge, Pennsylvania, April 21-24, 1996.

3. X. Gu and Shiao-Hung Chiang, "Removal of Emulsified Oil Particles from Wastewater," presented at the AIChE Annual Meeting, Chicago, Illinois, November 10-15, 1996.

4. X. Gu and Shiao-Hung Chiang, "Flotation: An Effective Unit Operation in Metal Oxide Separation," presented at 1997 AFS Technical Conference, Minneapolis, Minnesota, April 29May 2, 1997.

5. X. Gu and Shiao-Hung Chiang, "Modeling of the Multi-stage Column Flotation Process for Oil/Water Separation," presented at the AIChE Annual Meeting, Los Angles, California, November, 1997.

6. X. Gu, D. X. He, and Shiao-Hung Chiang, "A Novel Multistage Agitated Column For Separation Processes," 11, 39-47, Fluid/Particle Separation Journal.

7. D. X. He, X. Gu and Shiao-Hung Chiang, "A Study of A Multistage Column For Fine Coal Beneficiation," accepted for publication in Coal Preparation.

$\begin{aligned} & \text { Note: Copies of Paper No. } 1 \text { and } 6 \text { are attached with this Report. - Copyrighted-Not } \text { Not } \\ & \text { d canned }\end{aligned}$ 